\title{
大谷鉱山のシュリンケージ採鉱法と能率
}

正会員本島繁 夫*

\section{The Improved Shrinkage Stoping at Ôtani Mine}

\begin{abstract}
Shigeo HIRASHIMA
The Ôtani mine is located northwest of Kameoka city, Kyoto Prefecture, and owned by the Awamura Mining Co. Ltd.

The mine was shut down after the Second World War, but reopened in January 1951.

The scheelite ore deposits of Ôtani mine consists of narrow veins, averaging about $0.8 \mathrm{~m}$ wide with hard walls, and of wide veins, averaging about $2.20 \mathrm{~m}$ with weak walls.

For the narrow veins shrinkage stoping was practiced from the past, but in order to increase productivity the stope demensions were enlarged with the span being doubled to $40 \mathrm{~m}$, and height being doubled to $50 \mathrm{~m}$ by eliminating sublevel in between levels. The stall timberings used to prevent slabbing of the walls as a habit in the past were eliminated to a minimum. Furthermore, the hoists for materials and local fans were installed as required. By these improvements made the footage drilled increased by $65 \%$ and production per driller per shift increased by $63 \%$

After the shrinkage stope is mined out, waste fillings are used to prevent stope cave-in's.

Where the waste fillings are not available, concrete sills are set in on upper levels of the stopes to prevent rock falls and water seepage.

For the wide veins with weak walls the shrinkage stoping with square-set timbering were applied to support the back and side walls in the past. At present modified shrinkage stoping is being tried successfully. In the modified method roof balts are used in place of square-set timbering to pin the backs and side walls. Many chutes used in shrinkage stopes are eliminated to two chutes on the ends of the stope, and $5 \mathrm{H}$ air slushers are used to scrape the broken surplus ore into the chutes.

By so doing the constant friction and drag on the walls were decreased to prevent slabbing of the walls to a minimum.

By these improvements the production per driller per shift has been increased by 6 times. The mine production has been raised to 5,000t per month and the production per underground worker per shift has attained to $54.7 \mathrm{t}$.
\end{abstract}

\section{1. 緒言}

大谷鉣山は京都府亀岡市䕐田野町にあつてタングステ ン鉣 (灰重石)を産出している。京都駅から山陰線で 40 分亀岡駅で下車, 駅から平坦な道路を西方に $6 \mathrm{~km}$, 自 動車で15分の交通至便の地市る。大正 3 年，銅山とし て稼業中でめつた当山を莱村家が譲り受け，タングステ ン鉣山として発足したもので，当時わが国ではまだタン グステンの製鍊技術がないため，もつぱら鉱石のままド イッ輸出していたが，第一次大戦の余波を受けて休山 昭和11年再開, 第二次大戦中大いに生産に努めたが終戦 飞伴い休山した。眧和 26 年 1 月再開, 同 8 月重液選鉣法 などを新た棌用して選鉣場の改造完了試運転を始め, 坑内に括いては埋没坑道を取明け採鉱切羽の整䜤をな し, 採鉣計画並びに探鉱方釬を樹立, 漸次出鉣量を増加 し, その後綜合合理化計画も具体化して順調な操業を続 けケ，近代化された坑内となるに至つた。

* 株式会社粟村釷業所大谷鈗山採鉣課長
付近一带は丹波盈地の東縁汇当り山方低く, 地質注秩 父古生層嘱する粘板岩, 砂岩, 角岩とこれに貫入した 花崗岩とから成る。鉣床注花崗岩中に発達する石英質鉣 脈で, ほ汸平行に 20 数条数元ることが出来, その方向 は $\mathrm{N} 20 \sim 40^{\circ} \mathrm{E}$, 傾斜は $\mathrm{NW} 70^{\circ} \sim 80^{\circ}$ である。鉣石は 灰重石で黄銅鉣, 黄鉄鉣, 磁硫鉄鉣, 錫石等を随伴乙, 脈石は石英を主とし絹雲母, 螢石, 方解石等が見られる。 主要鉣脈群恃 80 100 $\mathrm{m}$ 間隔に雁行状に賦存し, からこ れらの鉣脈自体も上盤又は下盤に 5 $10 \mathrm{~m}$ 間隔に, 雁行 した数条の鉣脈から成つているのが普通である。鉣脈の 最大水平延長は $1 \mathrm{~km}$ に改び, 垂直延長性現在 $170 \mathrm{~m}$ 以上でな祘深部に続いて和り，脈幅は最大 $5 \mathrm{~m}$, 平均 1 $\mathrm{m}$ である。品位は部分的に高い籄所も㐫るが，平均し て $0.8 \sim 1.0 \% \mathrm{WO}_{3}$ である。鉱床は第 1 図の大谷鉣山と 宮前町とを結ぶ道に沿つた谷で二分し，南部地区と北部 地区にしているが，炤和 26 年再開当時には南部地区の通 洞坑準 (海抜 $141 \mathrm{~m}$ ) 以上は汪とんど採鈗を終つて扔り， かつ戦時中の濫掘増座の為に相当荒廃していたし，北部 


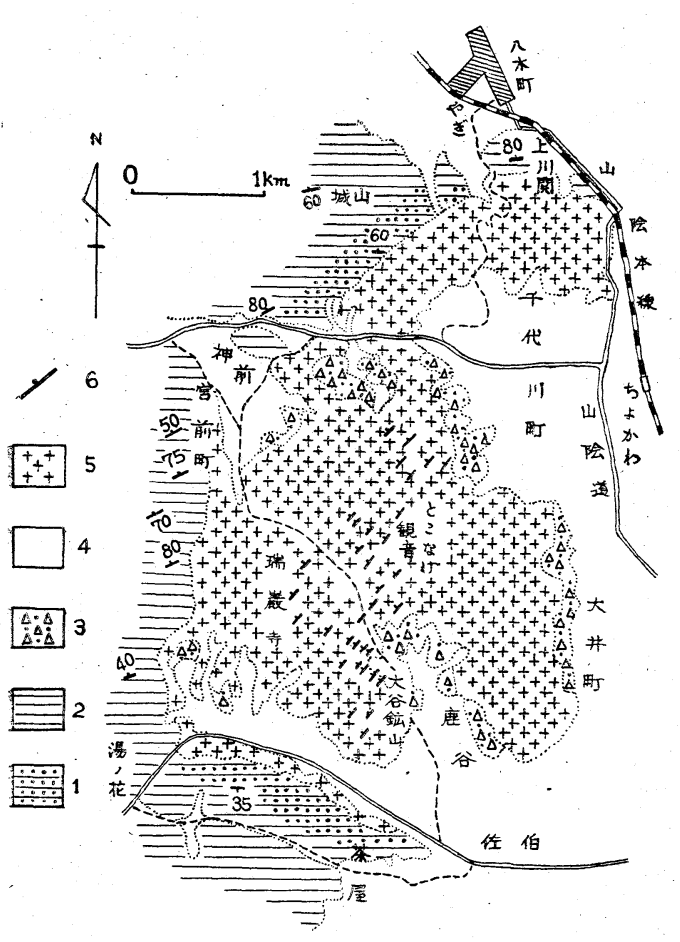

$1:$ 秩父古生層(接触変質した部分) $2:$ 秩父古生層 $3:$ 崩積層 $4:$ 沖積層 $5:$ 花崗岩 $6:$ 鈗脈の露頭

第1図、大谷鉱山付近の地質図(京大滝本清教授による)

地区怢未閉発状態のままであつた。したがつて取あえず 出鉣を必要とする当時であつたので，まず第一期畝画と して，南部地区通洞坑準以上の残釷の採鉣と，探鉱もれ 鉣脈の発見に努め，同時に下部開発安行うこととした。 第二期計画として北部地区を開発，第三期計画として南 部地区のさらに下部の開発を行う考えである。第一期計 画汇は立坑の開さく，機械化，能率改善等が含まれるが， 今回はその中から主として採鉱関する事項とそれて関 連する過程とを拔萃して報告する。

\section{1 工当り出鉱量增加の計画}

一般飞輸入タングステン鉣が低価格であり，市価の不 安定なこの種の鉱石に対して，低品位の当山が成立する 為には，極力 1 工当りの生産能率向上して，極度にコ スト安に生産することが必然的対策である。幸い下部開 発は新規開坑であるから, 生産能率向上達成のための計 画的坑道配置が容易でめつて, 将来出釷に险路を生ずる ことのない様, 充分注意を払うことが出来た。個々の作 業能率向上は勿論重要な事柄では嵓るが，それ以上にす べての能率のバランス, ことに, 個々の作業のジョイン 卜の空吵, 出釷量 (将来の拡張を見込んでの出釷量) と 設備, 機械力と人員, 採釷法々その操業等の関係を充分 検討乙て, 無䭾な設備, 過㮃の人員を作らない样注意を
払つた。

\section{$2 \cdot 1$ 立坑開さくと埋藏鉱量の確保}

立坑の位置法坑内の全作業がここを中心として発展す る関係上，埋蔵鉱量の添湆中央部で，坑内に打ける鉱石 運搬距離と坑外飞和ける選鉣場粗鉣ビンまでの運搬距離 との合計を最短にすることを第一条件とし，さらに付近 の岩盤の状態, 坑外との全般的な関係, 工事費等の点か ら第 2 図に示す位置に定めた。

立坑の構造法第 3 困汇示寸通りで, $20 \mathrm{~cm}$ 角松材をク レオソート油で処理し $1 \mathrm{~m}$ 間隔渀組したものである。 機械室を坑道面から $15 \mathrm{~m}$ 上にあげ，スキップのダンプ する状態を巻上夫が直視出来る様にし，スキップ，ロ一 プ，そのコース元等の点検や修理を容易にし，また保安 上からはスキップケージの過巻防止対策に種々の安全 装置の外, 視覚を重要視したものである。上部(山神坑) のズリビンは山神, 通洞両坑道に連絡してズリ充填を容 易にし，鉣石ビンは上部に $60 \mathrm{t}$, 下部 $(50 \mathrm{~m}$ 珫) 飞 $150 \mathrm{t}$ 計 $210 t$ の容量とし，眝鉣ビンといらょり単に鉱石を他 の運搬系統に積替觉る場所とし，出鉣を円滑に行い得る 最小限度のものを設計して, 不必要な大容量のものは造 らないこととした。

ケージは $1,200 \mathrm{~mm} \times 2,400 \mathrm{~mm} \times 2,350 \mathrm{~mm}$ (床面から 天井最下面までの高さ) の一段式ジュラルミン製で20人 乘りとし, 一挙に多人数の運搬, また蓄電車, ローダ一 等の機械類をそのまま積込み運搬出来る様大型のるのと した。単胴巻で運転速度は塔乘者に不快感を与兄ない程 度の $60 \mathrm{~m} / \mathrm{min}$ の低スピードである。スキップは 1,000 $\mathrm{mm} \times 800 \mathrm{~mm} \times 2,200 \mathrm{~mm}$ のものとし, その容積の 85 $\%$ 積込九で $2 \mathrm{t}$ 積載可能の複胴巻, ロープスピードは $100 \mathrm{~m} / \mathrm{min}$ で現在 $60 \mathrm{t} / \mathrm{h}$ の好理能力を有し, 将来の出 鉱量增加も考えて充分余裕を持たせる様に設計した。

$50 \mathrm{~m}$ 坑法汗る立入坑道は雁行した鉣脈之大体 $45^{\circ}$ で交叉させて，坑道の全延長が最短距離になる様にし， かつ坑道の複雑化を防ぎ, 列車運転による運搬を便利に した。銿押坑道は加背を大きくして採鉣隻備，保安に益

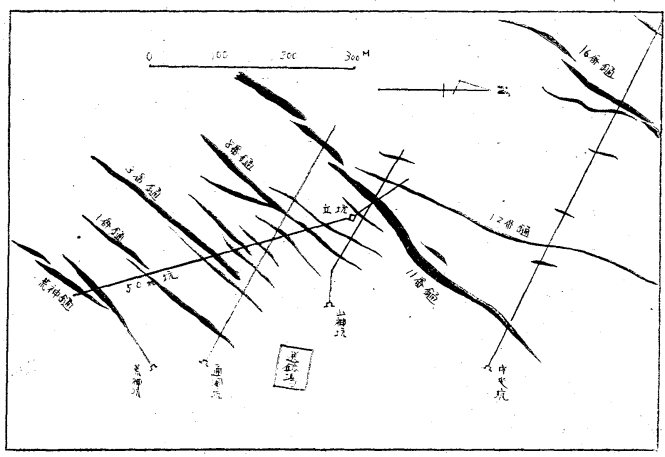

第2図南部地区鉱床図 


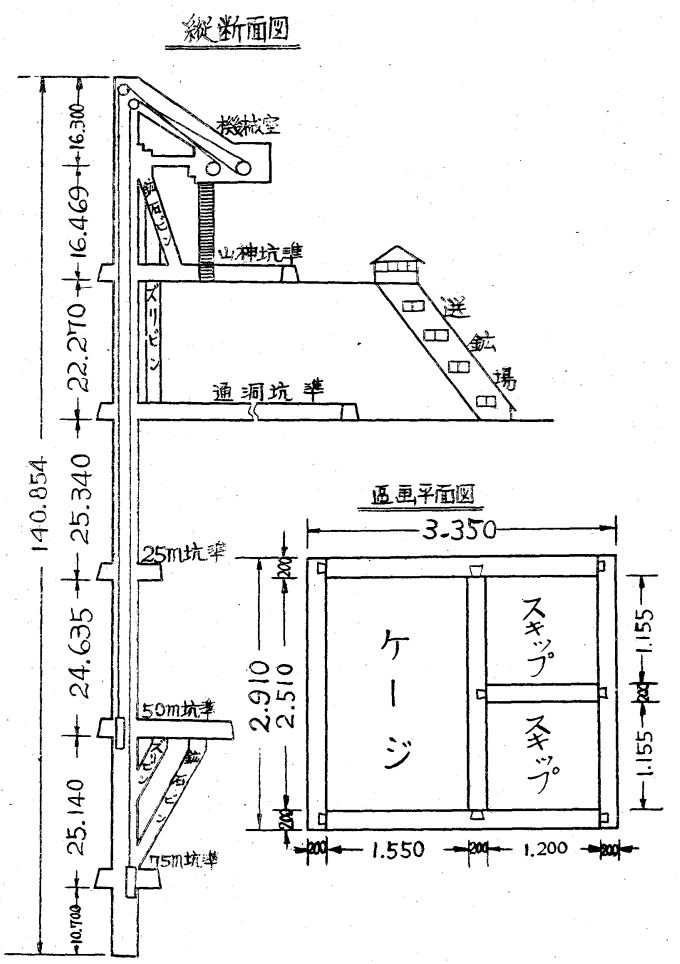

第3図立坑 の構造

するよう余裕のあるものとした。

立坑開さく完了と同時に $50 \mathrm{~m}$ 坑道掘進を進め, 漸次 獲得埋蔵鉱量を増加し，下部から月産 $5,000 \mathrm{t}$ 或いはと れ以上生産するための基礎を固めることが出来た。

\section{$2 \cdot 2$ 機械化による能率向上}

生産の完全な基礎準備完了に次いで，1工当りの出鉣 量を増加させるためには，作業を出来る限り簡素化し機 械化する必要がめつて, このためには新しい機械類の購 大や古い機械類の修理，改良に力を入れた。

主要立入扐よび銿押坑道掘進によつて一応鉱量獲得 したが，未知の鉱脈には長尺タガネ $(5 \mathrm{~m} の 7 / 8$ "六角中 架鋼にカ一チップを鉳付けしたもので，初めから１本で

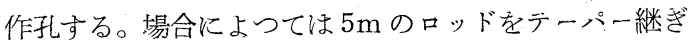
して $10 \mathrm{~m}, 20 \mathrm{~m}$ の作孔を行う) や長孔作孔(ソケット 継ぎした普通のもの）によるスラッヂ探鉣と， $150 \mathrm{~m}$ 能 カのコアーボーリング機によつて探鉣し，未掌握鉣脈の 捕捉汇能率を挙げまた経費を軽減している。

さく岩機惊昭和27年に ASD-31，7L，CC-11 等堂廃 して ASD-25, ASD-43 に切替えて小型軽量湿式化し, 同年コンプレッサーは $200 \mathrm{P}$ を増加して坑内動力源に 余裕をつくり，主要送気管を $4^{\prime \prime} か ら 6 "$ に切替方，坑 内環境浄化のために 6" リグレスを採用した。インサー

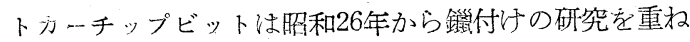

又種々のチップについて綿密な統計をとつて検討し，当 山に適するものを選定した。

運般ではバケットローダー， $0.75 \mathrm{~m}^{3}$ ·容量の自動連結 器定付したグランビー一型ダンプカーと $2 \mathrm{t}$ 蓄電車安従来 の手押鉣車と置換完，積计作業は 1 工当り約 4 倍, 漏斗 抜作業は約 8 倍の能率をあげている。末た選鉣場送鉱用

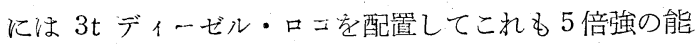
率交あ误得た。

その他種々の機械類をらやし, 坑内人員注自然減にま かせ機械为に上る作業量増加でこれを補い，かつ体力を 必要とする作業を激減させた。坑内の機械化は一応完了 しているがとの主なるの第1表に示す。

\section{$2 \cdot 3$ 本番賃金制度の堅持}

鈗山の貨金制度法一部の作業について，請負賃金制度 它採用するのが普通であるが，これ注その作業の能率に は良好な結果をるたらす反面，請負制度を採用出来ない 作業ではいわゆる片手落ちとなつて，全般的には人員の 配置记融通性と欠いて “むら”のある能率，作業結果と なり易い。又この方法は鉱山作業の最も大切な保安の確 保を全くするに少しく難点があり，めるいは鉣山の雾围 気良化の為には必ずしも芳しいものとは言えない。従つ てこれらの久点安補ら本番貴金制度で作業能率它向上さ せることが出来礼理想である。当山では最初から本番 顀金制度を堅持してこ机らを危惧することなく，作業能 率向上に努力を払つて来た。

第 1 表 坑内の機械化

\begin{tabular}{|c|c|c|c|c|}
\hline 類 & 名称・型式 & 製 作 所 & 力 & 台 数 \\
\hline 巻 上 機 & 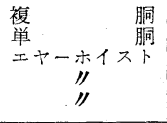 & $\begin{array}{l}\text { 住 } \\
\text { 油 友 } \\
\text { 态谷 } \\
\text { インガーンル }\end{array}$ & $\begin{array}{r}100 \mathrm{P} \\
100 \mathrm{P} \\
5 \mathrm{P} \\
3 \mathrm{P} \\
3 \mathrm{P}\end{array}$ & $\begin{array}{l}1 \\
1 \\
2 \\
2 \\
1\end{array}$ \\
\hline スうッシャ & $\begin{array}{c}2 ト ゙ ״ ム \\
\prime \prime \prime\end{array}$ & 告 & $\begin{array}{l}5 \stackrel{P}{\mathrm{P}} \\
5 \mathrm{P} \\
5 \mathbb{P}\end{array}$ & $\begin{array}{l}1 \\
1 \\
1\end{array}$ \\
\hline 機 関 車 & 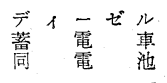 & $\begin{array}{l}\text { 妿 } \\
\text { 湯本翰藤 } \\
\text { 浅 }\end{array}$ & $\begin{array}{l}3 t \\
2 t\end{array}$ & $\begin{array}{l}1 \\
3 \\
5\end{array}$ \\
\hline 車 & 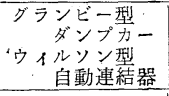 & $\begin{array}{l}\text { 白者振 興 } \\
\text { 日 立 }\end{array}$ & $0.75 \mathrm{~m}^{3}$ & $\begin{array}{l}15 \\
15\end{array}$ \\
\hline $\begin{array}{l}\text { バケットロ } \\
\text { ーダー }\end{array}$ & $\begin{array}{l}500 \mathrm{~B} \\
600 \mathrm{~B}\end{array}$ & 太”染 & & $\begin{array}{l}2 \\
3\end{array}$ \\
\hline 扇 風 機 & 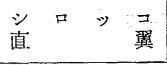 & 井上金属 & $\begin{array}{l}3 \mathrm{PP} \\
7.5 \mathrm{PP}\end{array}$ & $\frac{1}{1}$ \\
\hline さく岩機 & $\begin{array}{l}\text { ASD-25 } \\
\text { ASD- } 322 \\
\text { ASD-43 }\end{array}$ & 古 ${ }^{\text {河 }}$ & $\begin{array}{c}\text { レッグ 付 } \\
\text { ク } \\
\text { ク }\end{array}$ & $\begin{array}{r}22 \\
2 \\
22\end{array}$ \\
\hline そ の 他 & 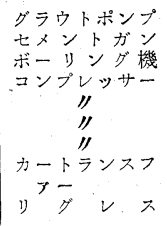 & 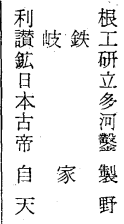 & $\begin{array}{l}\mathrm{Pn} 30 \mathrm{~kg} / \mathrm{cm}^{2} \\
1 \times 800 \mathrm{~F}^{2} \\
\text { OE } 3 \text { 型 } \\
200 \mathrm{P} \\
100 \mathrm{P} \\
100 \mathrm{P} \\
100 P \\
6^{\prime \prime}\end{array}$ & $\begin{array}{l}1 \\
1 \\
1 \\
1 \\
1 \\
1 \\
1 \\
5 \\
1\end{array}$ \\
\hline
\end{tabular}




\section{$2 \cdot 4$ クルー制の試用}

さく岩作業, 運搬作業, 支杜作業は密接な関倸にあつ てこれらの相互関連に喰違いがあると能率を阻害する。

したがつて充分綜合性を持たせる必要がある。当山坑内 に怙いてはこの点を特に重視し考慮して, さく岩作業で ほ種令の改良によつてさく孔能率をたがめてさく時間 空短縮し，運搬作業では機械化によつて筋肉学働方手先 の運軾操緃に改めて作業強度定減らし, 支杜作業でば切 羽の大ブロック化その他によつて作業量を減少させて, それぞれの作業に余裕時間を作り出し，この時間安利用 して自分の職務以外の作業の見習をさせた。このことは 本番賃金制度である為に容易に出来ることではあつた が，現在では相当程度の他職務の技術を習得させること が出来た。この試みは職務別の限界と技術差䒚くし, 将来はその差を除いてしまらことによつて，少人数で融 通性のある技術，能力で作業を行わんとするものであ る。いわ沛人員配置単純化のためのクル一制採用への 準備である。

現在すでに一部の坑道掘僬, 普通採鉱切羽で採用して いるが, さく岩作業, 支杜作業, 切羽運搬等字同一作業 筫が行らために，作業に無䭾な重複した過程が入らず極 めて能率が良い。又同一作業員が同一切羽で作業する関 係上常に切羽の状態を熟知しているので, 保安上からも 好成績を収めている。将来は全切羽に亘つて採用したい と考えている。

大略以上の計画遂行で鉱量, さ?岩, 運搬系統がほぼ 所期の計画に達するを得たので，採鉱法或はその能率如 何が 1 工当りの出鉱量に重大な影響をもつことになる。

次にその採鉱法について述べる。

\section{3. シュリンケージ探鉱と能率の推移}

当山の鉱脈は極めて採鉱の容易な好条件のものと, 極 めて採鉱の困難な黄条件のものとがあつて，採鉱法を決 定する上からは 2 種類に分けて考えた方が都合がよい。 すなわち幅の狭い鉣脈と, 幅の広い鉣脈とし, 前者は平 均幅 $0.8 \mathrm{~m}$ で鉱脈及び両盤共に硬く, 後者は平均幅 2.2 $\mathrm{m}$ で鉱脈の一部及び両盤の大部分が軟弱である。幅の 狭い鈗脈に対しては作業の容易さからシュリンケ・ジ採 鈗が適しているが，愊の広い鉱胍に対してはンュリンケ 一・゙採鉣が必ずしも好適な方法ではない。

\section{1 巾の狹い鉱脈の探鉱}

(1) 従来の採鉱法 下部開発以前の採鉱は坑道面か ら $25 \mathrm{~m}$ 上に中段坑道を切り，この間に長さ $20 \mathrm{~m}$ の切 羽家つくり，1ブロックとして, さく岩夫 1 名, 支杜夫 1 名, 同手伝 1 名で採鉱学行つた。両盤は一応しつかり しているが，それでも盤の虽脱和それて切羽には 1.0 〜 $1.5 \mathrm{~m}$ 間隔に打柱を施して盤受汀とした。この打杜は
あまり効果があつたとは思われないが習慣的なものであ つて, 坑木と支杜工数の増加を来たし, 更に悪いことに は,さく岩作業中スト・パーの移動を邪魔して作孔能率 を低下させ，又脱落打杜は鉣石抜取を阻害していた。採 鉣が進んで上部中段坑道下に 2 3m の鉣杜を残す程度 に達すると，この鉱杜に 2 箇所目抜をあけて採鉣を完了 し, 鉣石抜取後は無充填のまま放置した。中段坑道から 上も同様に採鉱したが，中段坑道枠，人道枠その他の坑 木類をあげるために，相当の労力と時間を要し採鉱の速 度能率は当然低下していた。

（2）改良した採鉱法 下部開発坑道の採鉣法核従来 の方法を改良して，採鉣切羽を４倍の大ブロックとして 長さ $40 \mathrm{~m}$ 高さ $50 \mathrm{~m}$ に集約し，かつ打杜を必要な最小 限度に減らし, 中段坑道を廃止した。切羽が $25 \mathrm{~m}$ 以上 にのほればエャ一ホイストを設備し，人道枠材料その他 の搬入容易にして支杜作業を容易にし, さく岩作業に 支障安来たすことのない樣にした。さく岩夫 2 名, 支杜 夫 2 名で作業を行い，切羽位置の高さにはほとんど閔係 なく, 1 工当りのさく孔数㤬来より $60.4 \%$, さく孔長 ほ54.8\% の上舁を得ることが出来た。

シュリンケージ採鉣では発破した鉱石を抜取る作業觉 迅速に行わなければ, その後の支杜作業, さく岩作業に 支障を来たす場合が多い。この対策には，発破をがた 後鉱石を抜取るべきその量と漏斗の番号をカードにさく 岩夫杂赎杜夫が記入する。2の方の列車（蓄電車+グ ランビー型ダンプカー5 台) がこのカードに示す通りに 順次抜取る。翌日 1 の方では抜き足りない僅かの量を抜 取るか，对度適当に抜けているなら，只足場をかきな らすだけで次の作業が行える。この列車の能率は1時間 に 25 車約 $35 \mathrm{t}$ である。

発破後の積入文はこの漏斗抜のための通気は, 自然通 気の充分な箇所は特別の対策を立ててないが，そらでな い箇所に対しては，3H，と7.5P の局部扇風機を設備し て, 上部坑道の新鮮な空気を送入し, 空気の浄化をはか つた。このため消煙待ち時間は少くとも30 分短縮し得 た。

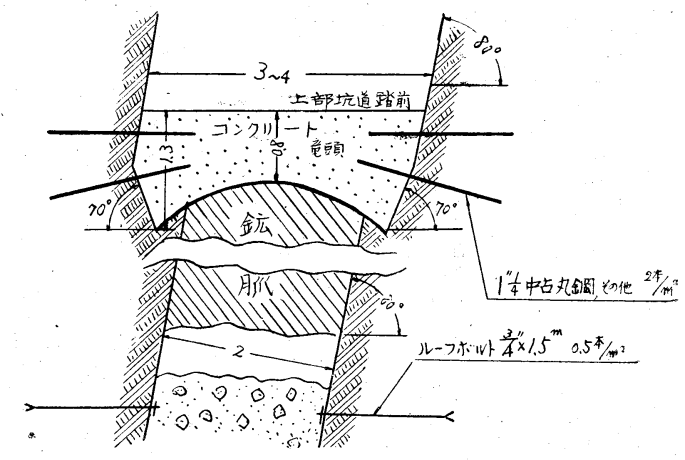

第 4 図コンクリート竜頭 (単位 $\mathrm{m}$ ) 
採鉣を完了し鉣石を拔取つた後はズリ充填を行い，保 坑を良くする様に妢めている。ズり充媜を当分行わない 切羽或は切羽に水が回つて浮石落下の危険が多い場合は 鉱石の実収率索たかめまた水を切る目的で, 上部坑道下 飞前以てコンクリート竜頭を造り，効果を期待している。 第 4 図はその一例を示す。

第 2 表は採鉱原単位の推移を示すが，表中昭和 31 年 8 月〜12月の成績は上述の改善した方法によるものであり 又さく岩 1 工当りの破砕立方性昭和 28 年度に比して，63 \%の増加を示している。

第 2 表 採釷原単位の推移

\begin{tabular}{|c|c|c|c|c|c|}
\hline \multirow{2}{*}{ 年 } & \multirow{2}{*}{$\begin{array}{c}\text { さと岩 } \\
1 \text { 工当 } \\
\text { m }^{3}\end{array}$} & \multicolumn{2}{|c|}{$1 \mathrm{~m}^{3}$} & b & \multirow{2}{*}{ 備 } \\
\hline & & 支柱工数 & 坑木石 & 爆薬 $\mathrm{g}$ & \\
\hline 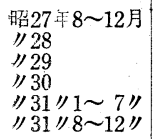 & $\begin{array}{l}3.10 \\
5.51 \\
6.07 \\
5.42 \\
6.39 \\
9.08\end{array}$ & $\begin{array}{l}0.65 \\
0.44 \\
0.31 \\
0.36 \\
0.35 \\
0.17\end{array}$ & $\begin{array}{l}0.18 \\
0.09 \\
0.09 \\
0.06 \\
0.08 \\
0.04\end{array}$ & $\begin{array}{l}824.6 \\
528.8 \\
530.0 \\
580.0 \\
614.0 \\
590.0\end{array}$ & 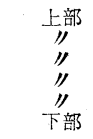 \\
\hline
\end{tabular}

\section{$3 \cdot 2$ 巾の広い鉱脈の採鉱}

幅の広い鉣脈の鉱量は当山の全鉣量の約 $1 / 3$ を占めてい るが，前述の通り両盤，鉣脈共汇軟弱で，さらに鉣脈之 両盤との間に断層肌が存在し, 加光て鉝脈自体汇方三角 目が発達している。したがって側壁の倒壊, 落盤が起り やすく採鉙する場合かなり危険で，乙かるズり混入率が 多くなる恐秃がある。鉱脈が硬い場合でも $30 \sim 50 \mathrm{~cm}$ 間 隔に棚目の入つていることが多く，余程熟練した作業員 でないと危険を伴う。

（1）従来の採鉱法 シュリンケージ採鉱法とスクエ ヤセット採鉱法を併用して切羽全面に枠組を行い，天盤 を受汗，側壁を押えて採鉱して来た。これは一応適当な 方法ではあつたが，模組するための坑木と側壁を围らた めの矢木が相当量必要であつて, 鉱石 $\mathrm{t}$ 当りの経費がか さみ，から採鉱完了までに長期間を要した。また仮りに 採鉙中側壁と鉣脈の条件が好転しても，次に悪くなつた 場合困るので，枠組を中止することが出来ない。さく岩 夫 1 名, 支杜夫 1 名, 同手伝 1 名で作業を行つたが, こ の様な方法のため幅の広、鉣脈の採鉣が送れ勝ちであつ た。

（2）改辰した方法 もし普通の掘跡充填シュリンケ 一ジ採鉣の適用が可能ならば，採鉣期間が短が，乙か

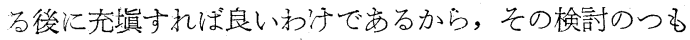
りで次の様な方法を数切羽で行つた。まずシュリンケー ジの方法にしたがつて準備し, 従来の枠組の代りにルー フボルトを使用し，切羽全面に漏斗抜を行ら代りに゙スク レーパを使用してスラッシングを行い，漏斗拔䇢所を1

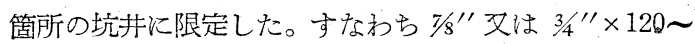
$150 \mathrm{~cm}$ のルーフボルトを打ち，特に細かい石目の多い
側壁に対しては，各ルーフボルトを割端材でつなぎ，そ れと側壁との間に矢木をさし込んで盤が党りを防止する こととした。5H のスラッシャー一を片方の人道に設置し

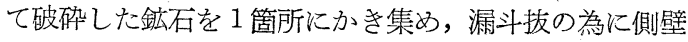
に不当な摩擦を与えて盤浮きを起すのを極力防ぎ，かつ ルーフボルトの効果を高める様にした。さく岩夫 1 名, 支杜夫 2 名で作業を行い従来の方法に比して採鉣速度が 速く, 4 倍或以はそれ以上でさく岩 1 工当りの破砕立方 も約 6 倍を示している。

第3 表 採鉱原単位の比較(幅の広い鉱脈)

\begin{tabular}{|c|c|c|c|c|c|c|c|}
\hline \multirow[b]{2}{*}{ 方式 } & \multirow[b]{2}{*}{ 眽幅 $\mathrm{m}$} & \multicolumn{2}{|r|}{$1 \mathrm{~m}^{3}$} & 当 & り & \multirow{2}{*}{ 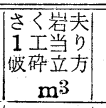 } & \multirow{2}{*}{ 備 } \\
\hline & & 爆薬 $\mathrm{g}$ & \begin{tabular}{|l|} 
卖柱 \\
数
\end{tabular} & 坑木 & $\left|\begin{array}{ccc}\mu & -7 \\
\mu & - & A\end{array}\right|$ & & \\
\hline $\begin{array}{l}\text { 従来 } \\
\text { 現在 }\end{array}$ & $\begin{array}{l}1.7 \\
2.0\end{array}$ & \begin{tabular}{|l|}
322.7 \\
328.8
\end{tabular} & $\begin{array}{l}0.76 \\
0.17\end{array}$ & $\begin{array}{l}0.346 \\
0.029\end{array}$ & 0.15 & $\begin{array}{r}3.07 \\
17.64\end{array}$ & $\begin{array}{l}\text { 照和 } 28 \text { 年上部 } \\
\text { 昭和 } 31 \text { 年下部 }\end{array}$ \\
\hline
\end{tabular}
困難と思われるさらに悪条件の箇所がまだあるので，そ こには充填採鉱を行うべく準備中である。な㧤充填材と しては選鉱場ロッドミル廃鉱中の +20 mesh の砂と, 重液選鉱の浮石 $-22 \mathrm{~mm}$ m $+6 \mathrm{~mm}$ を使用する予定で ある。

\section{4. 坑內人員に対する出鉱量の增加}

坑内人員活再開以来漸次増加して, 昭和28年度に掠い て120 名に達したが，それ以後は人員の補充を極力避 け，機械力を補充する方釬をとつた。その為め坑内人員 以自然退職汇よつて漸次減少して現在法昭和 28 年度上り も25\%だけ少くなつた。しかしこの間に一応の機械力が 整つたわけである。

第 4 表 採鉱構成人員 (昭和 32 年 7 月)

\begin{tabular}{|c|c|c|c|c|c|c|c|c|c|c|c|c|c|c|}
\hline & & 坑 & & 内 & $(90$ & & & & 坑 & & 外 & (18) & & \\
\hline 職 & 伍 & e & 支 & 道 & 搬 & 夫 & & 鉄 & 職 & 測 & ビ & 捈 & z & \\
\hline & & 岩 & 柱 & $\begin{array}{l}\text { 運 } \\
\text { 搬 }\end{array}$ & $\begin{array}{l}\text { 電 } \\
\text { 車 }\end{array}$ & $\begin{array}{l}\begin{array}{l}F \\
1 \\
1 \\
1 \\
\ddot{t}\end{array}\end{array}$ & 巻 & $\begin{array}{l}\text { 保線 } \\
\text { 穾 }\end{array}$ & & 量 & $\begin{array}{l}\text { " } \\
\text { ト }\end{array}$ & 車 & の & \\
\hline 員 & 長 & 夫 & 夫 & 夫 & 夫 & 夫 & 夫 & 他 & 負 & 夫 & 夫 & 夫 & 他 & 計 \\
\hline 6 & 1 & 18 & 21. & 25 & 5 & 2 & 4 & 8 & 2 & 3 & 4 & 3 & 6 & 108 \\
\hline
\end{tabular}

機械化による合理化の過渡期には，機械類に不慣れ， 急激な坑内の近代化の空気に不馴染及, 人員不足の為に 起業計画が遅々として谁行せず，生産に苦しんだが，日 を迫うにしたがつて次第に好転し全体的にそれぞれの能 力を充分発揮するに至つた。出鉱量は第 5 表に示す。

1 人 1 力月当りの出鉣量で示すと第 6 表の通りであ る。

上部坑道で最も順調に出鉱した昭和 28 年度は坑内 1 人 1 カ月当りの出鉱量は $30.26 t$ であつたが，下部に切替 
第 5 表 出 鉱 量

\begin{tabular}{|c|c|c|c|c|c|c|c|}
\hline 年 & 度 & 粗 & 鉣 量 $\mathrm{t}$ & 品位 & $\mathrm{WO}_{3} \%$ & 備 & 考 \\
\hline $\begin{array}{l}\text { 昭和 } \\
\text { "' } \\
\text { "' } \\
\text { "' } \\
\text { "' }\end{array}$ & $\begin{array}{l}26 \text { 年 } \\
27 \\
28 \\
29 \\
30 \\
31\end{array}$ & & $\begin{array}{r}7,668 \\
34,424 \\
43,570 \\
43,812 \\
44,609 \\
50,914\end{array}$ & & $\begin{array}{l}0.53 \\
0.48 \\
0.50 \\
0.53 \\
0.53 \\
0.53\end{array}$ & & 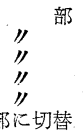 \\
\hline
\end{tabular}

第 6 表 1 人 1 カ月当りの出鉱量

\begin{tabular}{|c|c|c|c|c|c|c|c|c|}
\hline \multirow{2}{*}{ 年 } & \multirow{2}{*}{ 度 } & \multirow{2}{*}{$\mid \begin{array}{l}1 \text { 力月 } \\
\text { 出 } \\
\text { (鉱量 } \\
\text { (平坛) } \mathrm{t}\end{array}$} & \multicolumn{3}{|c|}{ (職員势含を) } & \multicolumn{2}{|c|}{$\begin{array}{c}1 \text { 人当り出鉱量 } \\
t\end{array}$} & \multirow{2}{*}{ 備 } \\
\hline & & & 坑 内 & 全 & 員 & 坑 内 & 全 員 & \\
\hline \multicolumn{2}{|c|}{$\begin{array}{lll} & \text { 昭和 } 28 \text { 年 } \\
\prime \prime \prime & 29 \\
\prime \prime & 30 & \\
\prime \prime & 31 & \text { 月 } \\
\prime & 32 \text { ” } & 5\end{array}$} & $\begin{array}{l}3,631 \\
3,651 \\
3,717 \\
4,243 \\
4,924\end{array}$ & $\begin{array}{r}120 \\
111 \\
99 \\
94\end{array}$ & & $\begin{array}{l}244 \\
231 \\
230 \\
228 \\
215\end{array}$ & \begin{tabular}{l|}
30.26 \\
32.89 \\
37.55 \\
45.14 \\
54.71
\end{tabular} & $\begin{array}{l}14.88 \\
15.54 \\
16.16 \\
18.61 \\
22.90\end{array}$ & $\begin{array}{c}\text { 上 } \\
\text { " } \\
8 \text { 月以降 }\end{array}$ \\
\hline
\end{tabular}

光て出鉣が正常を保つ様になつた昭和32年度に括いて は, 著しく増加し 1 月から 5 月までの平均で $54 \cdot 71 t$, 殊に 3 月に执いて $58.38 \mathrm{t}$ と飛躍的に上昇し, 平均 81 \%の间上を示すに至つた。ここに扎て一貫した第一期 計画の目的を充分に達成することが出来たわけである。

近来当社神崎川工場に於て当山廒の灰重石を原料とす る，高純度の金属メングステンの完成により，当山の灰 重石の供給量は重要な役割を持つ様になつて来た ${ }^{1) か ゙ ， ~}$ 以上述べた操業で $5,000 \mathrm{t} /$ 月の生産を行い供給している。

\section{5. 保安との 関係}

坑内作業はたとい高能率で作業学進めることが出来て も, 保安の確保を得なければ完全な作業とはいえない。 したがつてこの遂行にも努力を払つた。鉱床の構造から 落盤事故が多かつたが，危険切羽殊に落盤の恐れの多い 幅の広い鉱脈の採鉣には，作業前，作業中に常に天盤， 側壁を検査させ，且つ係員の巡回時にはさらに検討，討 議させてあらゆる方法を講じ，浮石処理の完全励行，作 孔特の棚目に対する仮打杜, 必要ならば安全筒所からの 長孔発破等によつて安全第一をはかり，その效果を挙げ て来た。その結果保安成績は向上し，近く 1 方年無災害 の記録学糛立せんとしている。

\section{6. 結}

論

コスト安に生産する為に，肉体的労働を知能的操縦作 業に切替学て坑内作業の近代化と各作業のバランスのと れた合理化をはかり，本番貨金制度を堅持しヌクルー制 を試用してさらに個々の作業の関連性をたかめるなど， 坑内を“こじんまり”とまとめて来た。先の結果一応目 的を達成し坑内 1 人当りの出鉱量は倍加するという極め て良好な成績を収めるに至つた。採鉣法に関しては幅の 狭い鉱脈では切羽を $40 \mathrm{~m} \times 50 \mathrm{~m}$ の大ブロック化，幅の

1) 那須重治 : 栗村鉣業所のタングステン製鍊, 日本航業会誌 72 巻 822 号 昭和 31 年 12 月 919 925頁
広い鉣脈ではルーフボルトとスクレ一パの活用によつて 一応成功を収め得た。今後さらに好成績を収めるために これらの著しく採鉱条件を異にする鉣脈の採鉣法をより 改泉して，他の合理化された系統をこれにマッチさせる ことが必要と考えられる。将来この問題の研究に努力を 払いたい。最後に上司の適切な御指導，係員の熱心なる 御努力と研究, 従業員の御協力によつて, この目的が汪 ぼ達成され得たことを述べて謝意を表したい。

（編集係註）本編は特集号の原稿として打願いしたも のでなく，本会誌へすでに投稿されてきていたのをその 杰ま，特集号の中に集録させて頂いた。内容や形式に他 と幾分の差異があると思われるが御了承されたい。

\section{係長による事故の報告書}

アリゾナ州 Ray and Hayden. 鉱山 (Kennecott Copper Corp.) の保安委員会で定めている係長が提出 す心゙き，事故の報告書は次のようなるのである。

係長による事故の報告書

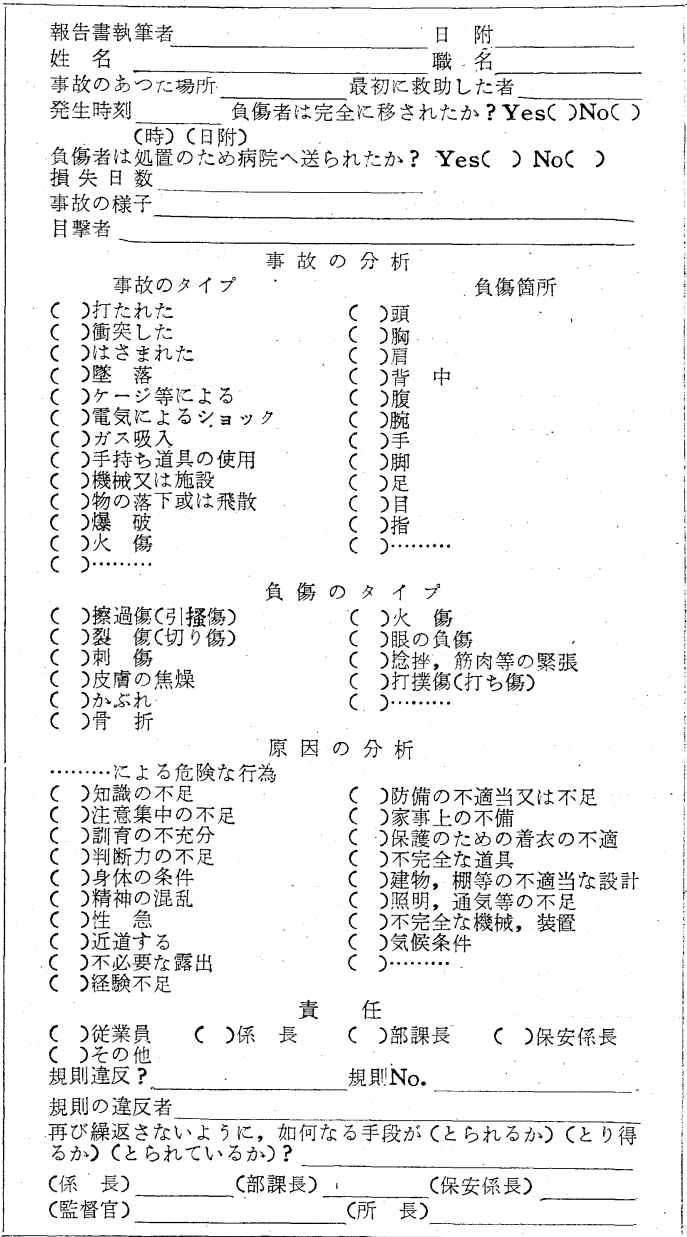

(Eng. \& Mining J., July 1975 p. $80 \sim 83$, A. D. Look \& M. L. Williams : Ray Mines' Safety Plan Pays Off より) (山 口) 